\title{
ANCAMAN TERHADAP DASAR NEGARA "PANCASILA" BAGI RAKYAT INDONESIA DALAM BERBANGSA DAN BERNEGARA
}

Oleh Heru Santosa Ir,MHum.

Dosen MKU,UPN Yogyakarta

\begin{abstract}
INTI SARI
Bangsa Indonesia yang setengah - setengah melaksanakan dasar Negara Pancasila sekarang ini banyak kendala - kendala yang timbul. Dari situ pertama tentang kehidupan keagamaan banyak terjadi gesekan - gesekan keyakinan di dalam masyarakat sehingga timbul anarki atau bertindak hakim sendiri. Demikian juga sila kedua tentang kemanusiaan sudah mulai hilang rasa kemanusiaannya. Persatuanpun sudah mulai memudar dan demokrasi juga hanya kelihatan semu karena hanya memikirkan kepentingannya sendiri sehingga timbul rasa keadilan yang tidak merata. Maka dengan demikian bangsa Indonesia sudah selayaknya kembali dengan dasar Negara Indonesia Pancasila secara lahir batin dalam melaksanakannya, baik dari segi dasar Negara sebagai segala sumber hukum atau sebagai Pandangan hidup Bangsa. Untuk mengejawantahkan kesejahteraan bangsa Indonesia dengan mendanai lembaga-lembaga riset yang dapat di harapkan hasil produksinya untuk kesejahteraan bangsa Indonesia sehingga mengurangi ketergantungannya produk-produk dari luar. Satu kata kunci : mandiri.
\end{abstract}

\section{A. PENDAHULUAN}

Bangsa Indonesia hingga sekarang ini masih belum menemukan jati dirinya bahkan oleh pendiri bangsa sudah di buatkan dan sudah di-kristalisasikan tinggal melaksanakan, tapi kenyataannya sekarang ini banyak dilupakan,disingkirkan karena adanya keragu-raguan baik dari elemen paling atas hingga paling bawah. Bahkan semua meremehkan apa yang namanya "Pancasila" itu. Terus bagaimana dengan hal in, akankah berlanjut atau cukup sampai disini saja. Demikian pertanyaannya. Kalau kita melihat fenomena di dalam masyarakat sering terjadi bentrokan antar agama, antar manusia mengenai hak - hak yang melekat pada manusia banyak dilanggar. Persatuan kita semakin pudar antara satu dengan yang lain saling memburu kepentingannya sendiri -sendiri. Demikian juga dengan politikus-politikus kita baik yang ada di pusat atau yang ada di daerah hanya memikirkan kebutuhannya sendiri tanpa memperdulikan masyarakat yang masih membutuhkan perhatian. Lebih ironisnya lagi sekarang ini orang hanya akan mengatakan mana kesejahteraan dan keadilan sosial yang dijanjikan di dalam "Pancasila" tersebut tidak dapat dibiarkan upaya meng- 
utak-atik Ideologi yang melelahkan dan hanya akan membuang banyak energi, mengacaukan konsentrasi bagi proses pembangunan dan perubahan Bangsa Indonesia akan tertinggal jauh dibelakang jika tidak membulatkan tekat memacu kemajuan seperti yang dilakukan banyak bangsa belakangan ini. Pembangunan merupakan upaya menciptakan kesejahteraan sesuai dengan amanat Pancasila, konstitusi dan proklamasi 17 Agustus 1945 (Bikard Bagun,Kompas Senin 16 Agustus 2010).

Sampai sekarang belum terlihat jelas upaya mewujutkan nilai sila - sila Pancasila secara sungguh - sungguh, tidak pernah sepenuh hati di laksanakan secara kongkret. Jangankan dilaksanakan dengan kesungguhan , keinginan membicarakan cenderung ogah-ogahan belakangan ini. Sudah mati angin , Pancasila terkesan seperti di telantarkan. Upaya mewujudkan nilai - nilai Pancasila selama ini terkesan setengah hati tidak banyak yang peduli jika Pancasila diganggu oleh Ideologi lain. Tidak ada kegairahan tinggi yang mampu mengartikan Kesaktian Pancasila terus menerus agar Pancasila semakin berakar kuat dalam kehidupan berbangsa dan bernegara. Tanpa banyak disadari penghayatan dan pengamalan Pancasila menjadi kedodoran. Semakin terasa kegamangan dan kehampaan mendalam, The Existensial Vacum, jika Pancasila di biarkan merana.

\section{PANCASILA BERFUNGSI INTEGRATIF.}

Sadar atau tidak, Pancasila mempunyai fungsi integrative yang menjamin kesatuan Negara bangsa Indonesia yang pluralistic. Taruhannya tidak kecil jika Pancasila dilecehkan, lebih - lebih karena posisinya sebagai dasar eksistensi Negara Proklamasi 17 Agustus 1945. Tidaklah berlebihan jika Pancasila menjadi salah satu kekaguman dunia luar terhadap Indonesia karena mempunyai fungsi menyatakan masyarakat dan wilayah Nusantara yang begitu luas, dengan berbagai latar belakang suku, budaya, bahasa, dan agama.

Perlu diketahui bahwa Pancasila merupakan warisan luar biasa pendiri bangsa yang mengacu pada nilai - nilai luhur, yang bersifat original dan tahan zaman. Sungguh warisan nilai yang sangat luar biasa. Tantangan sekarang yang ada adalah rumitnya bersifat sosiologis, sampai sekarang ini masih banyak terdapat kerancuan tentang pemahaman, penghayatan ke Indonesiaan. Tidak sedikit anggota masyarakat belum menempatkan dirinya sebagai warga Negara yang harus tunduk kepada ideologi Pancasila dan konstitusi UUD' 45.

Masih banyak pula yang mencampur- adukan pengertian sebagai warga Negara dengan posisi sebagai anggota kelompok etnik, budaya, bahasa, dan agama. Sebagai dampaknya, bukannya tunduk kepada Pancasila dan konstitusi Negara tetapi justru menggugatnya.

Eksistensi Negara bangsa Indonesia yang pluralistik terancam tamat jika dasar Negara Pancasila dan konstitusi UUD 45 tidak dijadikan ukuran dan acuan dalam berpikir serta berperilaku sebagai warga Negara. Sudah menjadi tugas semua anggota masyarakat terutama pemerintah untuk menberikan kawalan terhadap dasar Negara Pancasila dan konstitusi UUD 45. Pemerintah bahkan memiliki wewenang istimewa untuk menindak warga yang tidak tunduk pada dasar Negara dan konstitusi. (Andi Suruji, Kompas, Sabtu 14 Agustus 2010),. 


\section{DEGRADASI SOSIAL KEAGAMAAN}

Menyaksikan proses kehidupan bernegara dan berbangsa Indonesia akhir- akhir ini, potensi kemungkinan Indonesia menjadi "Negara gagal" semakin besar. Mengacu pada pernyataan Francis Fukuyama, ancaman terbesar abad ke 21 adalah " Negara gagal”, ditandai antara lain kemiskinan, pengangguran, konflik antar kelompok, dan merebaknya aksi terror.

Untuk kasus aktual Indonesia, pernyataan Fukuyama lima tahun lewat itu terlihat dalam kasus - kasus pembiaran rakyat menyaksikan sendiri masalah - masalah yang membelitnya, seperti kenaikan tarif listrik, kemiskinan, gas meledak, perilaku korupsi dan terinduksinya keluhuran politik jadi sekedar politik praktis berdurasi pendek, kerdil dan bernuansa sempit. Kekerasan yang merebak dalam berbagai bentuk terjadi semakin seporodis dengan tingkat semakin massif dari yang fisik hingga simbolik, mengidikasikan berkembang suburnya sisi kekerdilan manusia, cara berpikir dan bertindak atas nama idiologi agama, tetapi sebenarnya membenarkan doktrin sempit agama, menegaskan entakan Fukuyama semakin mengancam. Meskipun kita boleh menghibur diri, potensi " Negara gagal" perlu dihadapi, tidak dengan menaifkan, tetapi meletakkannya sebagai kemungkinan yang menantang untuk kritis dan mencegahnya. Itu karena kita hadapi tidak hanya kritis identitas, tetapi juga kritis intelektual dan hati nurani (aklak dan moral) yang mencerminkan kristis karakter bangsa. (Soemarno Soemarsono, karakter mengantar bangsa dari gelap menuju terang, PT Elex Komputindo, 2009). Karena pembangunan karakter diabaikan. Kondisi bangsa Indonesia sekarang ibarat " Gunung es" kelihatan gagah perkasa tetapi jiwa dan fondasinya rapuh.

Kondisi Indonesia saat ini, menurut Soemarno serupa yang dikhawatirkan Mahatma Gandhi tentang tujuh dosa yang mematikan, meliputi berkembangnya nilai dan perilaku budaya kekayaan tanpa bekerja, kesenangan tanpa nurani, pengetahuan tanpa karakter, bisnis tanpa moralitas, ilmu pengetahuan tanpa kemanusiaan, agama tanpa pengorbanan.

\section{AKTUALISASI PANCASILA}

Memungut Pancasila sebagai referensi kekayaan peradaban, warisan bapak bangsa dan menempatkannya sebagai antisipasi ke cenderungannya ke " Negara gagal" ibarat berseru di padang pasir. Padahal dalam kondisi menemukan kekayaan budaya Indonesia bagian dari obsesi mengenai tanah air dan merajut Nusantara itu aktual untuk mencegah pelapukan saat ini, yang diatributkan ketidakmampuan kita memanfaatkan arus globalisasi dan neolibralisme. Kegagalan menghadapi perkembangan dunia yang serba cepat.

Repotnya warisan leluhur yang dipuji berbagai pokok dunia itu, karena kesalahan praktik pemerintah orde baru yang menjadikannya mesin indoktrinasi politik, Pancasila dianggap sudah apak - basi. Kelima sila dengan inti dasarnya kemanusiaan ( N Drijarkara, karya lengkap Drijarkara, Kanisius, 2006), mengerucut pada sila pertama Ketuhanan yang Maha Esa, itu dianggap tidak relefan. Tidak hanya tidak dihayati, dihafalkan anak disekolahpu tidak, apalagi dipraktiskan dalam praktis kehidupan bernegara dan berbangsa. Go to hell Pancasila. 
Padahal kelima sila Pancasila merupakan rumusan nilai - nilai dan cita - cita yang hidup dalam masyarakat, rumusan dalam konteks obsesi bersama membentuk Negara kesatuan yang dipercaya dan perlu terus diperjuangkan.

Menyangkut bentuk Negara, berdasarkan agama atau nasionalisme, terjadi perdebatan panjang sebagaimana akhirnya ditemukan kesepakatan, antara lain mengerucut dalam lima sila Pancasila. Karena itu anjuran aktualisasi dan revitalitas merupakan keharusan yang ditempatkan tidak hanya dalam mewujudkan sila - sila Pancasila terutama dalam konteks ini sila pertama, tetapi lebih jauh lagi dalam kaitan hubungan antar agama dan Negara.

Munculnya perda - perda syariah bermasalah menyangkut proses ke beragaman , merebaknya partai - partai politik berdasarkan agama, menunjukkan belum selesainya tuntasnya hubungan agama dan Negara, yang menyangkut dua hal pokok: Pertama, hubungan Negara dan agama, dan kedua implementasi prinsip Negara berketuhanan dan konstitusi.

Padahal sejak awal sudah disadari realitas kemajemukan sebagai berkah. Kemajemukan itu disyukuri, dikembangkan dan ditempatkan sebagai batu sandi dasar Idiologi bernegara. Keberagaman tidak bersifat hierarkhis, melainkan egaliter, karena itu berimplikasi pada nilai etis toleransi. Dalam pemahaman beragaman-pluralisme multi kulturalisme sebagai toleransi dan kerukunan hidup beragama terbentang tarik ulur.

Ketika kita menerima sejumlah agama resmi, berarti eksistensi agama - agama itu diakui sebagai kompetitor yang sah dalam menyebarkan dan menjalankan agama masing - masing. Sudah dengan sendirinya terjadi gesekan di antara agama yang satu dengan yang lainnya, tetapi juga dalam agama - agama itu sendiri. Fanatisme tidak dibenarkan dalam agama apapun, apalagi kalau keberagaman diwujudkan dengan cara - cara ekstrim yang menempatkan agama sendiri sebagai kebenaran mutlak satu - satunya. Kebenaran atas keyakinan sendiri dibenarkan sejauh tidak dipaksakan pada pemeluk agama lain.

\section{DIMENSI HORIZONTAL}

Dimendi moral yang disebut sebagai kesalihan sosial bermakna memiliki kepedulian berhubungan secara harmonis dengan lingkungan,sekaligus meninggikan martabat kemanusiaan. Kesalihan sosial merupakan amunisi kritis sosial. Agamapun seperti dilambangkan Peter L Berger, etika pratutanisme, dalam agama Islam di Indonesia seperti dirintis KH Ahmad Dahlan lewat Muhammadiyah seabad lalu,merupakan terobosan keberagamaan tidak terhenti pada kesalehan ritual tetapi juga berdampak pada kehidupan sosial kemasyarakatan. Dalam praktek kehidupan berbangsa dan bernegara saat ini kesalehan terhenti di tingkat ritual, tidak dalam proses pemerintah.

Sila pertama ketuhanan Yang Maha Esa, kerucut dari keempat sila lainnya, tidak selesai dihafalkan, tidak selesai sebagai doktrin kekuasaan, tetapi perlu terus dikembangkan sesuai dengan tuntutan zaman. Sementara disaat ini, kalau ditingkat ideologi perlu diselesaikan masalah hubungan agama dan Negara, di tingkat Negara praktis perlu dicegah bahayanya kesalahan sosial. Dengan itulah kita mencegah kemungkinan terjadinya "Negara gagal" Francis Fukuyama, tidak dalam arti " gagal " secara hukum formal politik, tetapi dalam arti mandulnya eksistensi Negara. Wujudnya, ketentuan 
perundang - undangan tidak dipakai sebagai alat dan pedoman melaksanakan tindakan, sebaliknya kasus - kasus perda syariah yang dibuat beberapa pemerintah daerah mencerminkan betapa peraturan dibuat tidak didasarkan atas kondisi kepentingan umum, melainkan pemahaman keberagamaan yang sempit. Yang dilalaikan adalah realitas pluralism Indonesia sebagai berkah dan kekayaan yang harus di tempatkan sebagai batu sandi, sementara begitu realitas ini ditinggalkan, berarti Negara membiarkan kebebasan beragama dam beribadah terancam. Mencegah bangkrutnya kesalahan sosial ditingkat masyarakat aktual berarti menjadikan penegakan hukum sebagai aturan main dan sebaliknya kegamangan atas nama rakyat. Hadirnya fungsi pemerintah yang eksekutif dan tidak gamang dalam keberpihakan demi kepentingan bersama dan keharmonisan hidup beragamaan dalam masyarakat yang majemuk, kita menantang masa depan Indonesia merdeka tanpa dicekoki kekhawatiran menuju “ Negara gagal”. ( ST Sularto, Kompas Selasa, 10 Agustus 2010 ).

\section{B. DEGRADASI KEMANUSIAAN YANG SUDAH MERAMBAH.}

Kekerasan terus - menerus terpapar, menjadikannya seperti tontonan pornografi yang dinikmati diam-diam. Selain kekerasan politik yang melenyapkan hidup jutaan warga dan meninggalkan trauma sejarah, sejak tahun 1965, kekerasan terus terjadi, susul menyusul, vertikal maupun horizontal menyangkut soal publik maupun privat, termasuk pelanggaran kebebasan beragama dan berkeyakinan. Kekerasan yang merampas hak - hak sipil dan politik berkelanjutan dengan perampasan hak - hak ekonomi, sosial dan budaya. Situasi ini tidak dapat disederhanakan hanya sebutan "Warisan Orde Baru” yang militeritik dan melindungi impunitas para pelakunya. Sampai 10 tahun setelah "Reformasi " 1998, Negara tak hanya gagal membangun system dan legitimasi untuk menolak kekerasan. Sebaliknya kekerasan justru digunakan atas nama “ mendisiplinkan dan melindungi nilai - nilai moral dan ajaran " dari satu perspektif kebenaran logika hukum " mayoritanisme " atas nama Demokrasi menghasilkan kebijakan - kebijakan yang diskriminatif dan menciptakan tekanan hidup yang melahirkan beragam tindakan kekerasan terhadap orang lain, anggota keluarga, maupun diri sendiri. Rentetan peristiwa kekerasan bergerak seperti kilat berebut menghuni ruang ingatan, sampai melupakan daya tampungnya. Orang menjadi cepat lupa, bahkan menganggap kekerasan seperti hal biasa, the banality of evil, meminjam istilah filosof Hanuah Arendt.

\section{PARODI}

Disisi lain, banyak orang tidak risi memamerkan kekayaan, ditonton jutaan orang mengais sisa rejeki untuk bertahan hidup. Iklan - iklan yang menawarkan gaya hidup mewah bertebaran ditonton orang - orang dengan perut lapar dan mata kosong.

Tuntutan masyarakat yang kehilangan hak hidup akibat kesusahan sosial, ekologis dan perampasan sumber daya menjadi seperti parodi. Para pelaku, penguasa sumber daya ( ekonomi dan politik), taksulit menuntut balik untuk membalikkan posisi korban sebagai pelaku kekerasan. Kemanusiaan menampakan wajahnya saat terjadi bencana. Namun tak sulit juga menengarai solidaritas itu semua dan tersebut bersifat karitatif dan sangat sementara. Bahkan tak sedikit yang memanfaatkan untuk kepentingan politik, melalui umbul - umbul bernuansa keagamaan dan bendera berlambang partai. 
Selama bermartabat warga tak dididik belajar menghormati hidup, sebaliknya terus - menerus dipaksa belajar berlutut di hadapan kekerasan untuk kemudian ikut memproduksi dan mereproduksi kekerasan. Sejarah Negri ini mengenal kekerasan dalam spektrum luas, mulai dari amuk masa dan kekalapan tak terkendali (amuk) sampai - sampai kekerasan pasif, seperti pepe, tindakan protes dengan menyakiti diri sendiri. Warga tak pernah dididik secara sistematis untuk belajar bernegosasi dengan kedudukan setara sehingga membuat wajah kekerasan tampak makin rakus dan keji. Juga tak terlihat pembelajaran tentang dampak kekerasan, seberapa kejam dan luas skalanya.

\section{KEWARGAAN PUBLIK}

Ketika penglihatan tak tampak makin tidak cukup produktif menghadapi kekerasan, pendekatan kewajiban dan tanggung jawab warga untuk masuk ke wilayah kepengurusan publik yang multi skala, dimulai dari ruang - ruang hidup ditingkat paling bawah, seperti RT dan dukuh, tampaknya harus dipikirkan suara serius. Gagasan ini terkait dengan ide kewargaan publik yang tak tersikat dan multi skala, dengan landasan syarat kesatuan sosial, ekologis yang harus terus dipelajari. Gagasan ini bisa dibaca rekam jelajah pemikirannya dari para ilmuwan dunia, secara antropologis di bedah antara lain oleh antropolog, Amerika Serikat, Ann Stoler. Diyakini mampu membongkar dan melucuti wajah kekuasaan dan kekerasan struktural Negara yang dihasilkannya. Contohnya sudah terlihat di Negara - Negara yang demokrasinya sudah mapan, seperti di AS dan Negara - Negara di Eropa diantaranya Perancis dan Jerman. Kewargaan publik tak bersifat disatukan kesadaran bahwa keberlangsungnya hidup dan kehidupan hanya bisa diciptakan dengan menjaga, melindungi dan memelihara secara bersama ruang - ruang hidup.

Dari sini warga belajar menghormati diri sendiri , orang lain dalam dan kemanusiaan dan terus bernegosiasi dengan siapapun, diatas pilihan dan pengamatan pada hidup dan kehidupan.

Kesadaran akan pengelolaan bersama ruang hidup membuat keberadaban dan keadilan sebagai nilai - nilai yang menyatu dalam diri warga, membuat persoalan mayoritas - minoritas tidak lagi relevan. Demokrasi tidak menukik pada substansinya. Pemahaman akan sejarah kesatuan sosial - ekologis membuat pendidikan kebangsaan kembali pada sisi pembukakaan konstitusi, suatu pilihan kebangsaan tak bersekat nasionalisme yang bermakna luas. Barangkali dengan gagasan ini, sila kedua Pancasila, kemanusiaan yang adil dan beradab, menemukan maknanya.

\section{PERSATUAN YANG SEMAKIN MEMUDAR}

Ada titik - titik dalam perjalanan itu dimana kita merasa tidak mencapainya, tetapi tidak sedikit pula titik dimana kita merasa kehilangan persatuan bahkan oleh sebagian di yakini sebagai benang merah perjuangan Bapak bangsa Bung Karno sebagai pemimpin yang mendominasi panggung politik Nasional dan tokoh yang fasih mengartikulasikan ide, panggung hidup di hati Bung Karno kemudian bergaung luas di tengah - tengah rakyat Indonesia. Memang ada serangkaian upaya untuk memecah Indonesia, tetapi NKRI tetap utuh bahkan setelah Bung Karno pergi.

Pak Harto punya visi dan cara mempersatukan bangsa yang lain lagi. Didukung oleh teknologi. Sekilas mendiang Iskandar Alisyabana, Indonesia disatukan oleh satelit palapa. Saat Palapa A1 
diluncurkan tahun 1976, Indrenesia menjadi Negara ke empat dunia yang memanfaatkan satelit komunikasi domestik. Dengan tehnologi satelit itulah sambungan langsung jarak jauh (SLJJ) dimungkinkan, siaran televisi dari Jakarta.

Pertanyaannya " bersatu dalam keragaman apakah historis atau utopia " dapat kita jawab dalam dua aspek. Bung Karno dan pemimpin berikutnya telah menjawab bagiannya masing - masing. Jadi historisnya ada, namun selanjutnya ia bisa jadi utopia manakala para pemimpin dan kita semua lalai memgerjakan tanggung jawab masing - masing. (Ninok Laksono, Kompas, 12 Agustus 201 hal 1).

\section{DEMOKRASI MASIH COBA - COBA.}

“ Kita coba ingin menjadikan Indonesia laboratorium demokrasi..., tetapi begitu penting dan strateginya perubahan UUD' 45, maka semua pihak harus mengesampingkan kepentingan sesaat, kepentingan sendiri, atau kepentingan kelompok"

Itulah pandangan Fraksi TNI/ Polri yang disampaikan juru bicaranya, Christina M Rontatena, dalam sidang umum MPR, Sabtu 10 Agustus 2002. Sikap politik yang disampaikan sebelum pengesahan perubahan UUD' 45 yang ke empat sempat memunculkan ketidakpastian dalam siding umum MPR. Namun melalui proses lobi, ketegangan itu mulai cair.

Tengah malam, ketua Fraksi TNI/Polri Slamet Supriyadi maju ke podium dan berpidato, " Fraksi TNI/ Polri tidak ..ioberniat menghambat amandemen UUD' 45. Karena itu, Fraksi TNI/ Polri menarik usulan pembentukan komisi konstitusi di dalam aturan tambahan UUD' 45".

Suasana lega Ketua MPR Amin Rais mengetukkan palu tanda di syahkannya perubahan UUD' 45, Sabtu 10 Agustus 2002, pukul 23.55. Indonesia memasuki era baru dengan konstitusi yang subtansinya baru. Sebuah revolusi dalam sistem pemerintahan Indonesia. Waktu terus berjalan, Bangsa Indonesia terus melangkah meskipun jatuh bangun dalam membangun demokrasi

Diawali dengan demokrasi parlementer atau demokrasi liberal (1950 - 1959), demokrasi terpimpin (1959 - 1966) dibawah Soekarno, menuju demokrasi Pancasila (1967 - 1998) dibawah kontrol Soeharto. Ketiga model Demokrasi itu tidak berakhir dengan baik. Pasca Orde Baru , demokrasi sedang mencari bentuknya, entah menuju demokrasi liberal atau model lain. Demokrasi di Indonesia lebih ideal bilamana tidak seperti sekarang ini. Parta - partai tidak sebanyak sekarang sampai belasan partai, dan partai - partai tersebut dapat disederhanakan menjadi lima partai dan penamaannya disesuaikan dengan lambang - lambang dalam Pancasila. Untuk demokrasinya jelas bukan Demokrasi Liberal dan bukan demokrasi terpimpin. Hal ini untuk menghindari politikus kutuloncat dari partai satu ke partai yang lain. Bangsa Indonesia mantap mempunyai 5 partai dan Amerika mempunyai dua partai. Dan bangsa Indonesia berdemokrasi di bawah Dasar Negara Pancasila. Pemilihan Presiden langsung adalah revolusi, bukan hanya presiden yang dipilih lansung saja, tetapi Gubernur, Walikota, Bupati juga dipilih langsung. Ini pertama kalinya dalam sejarah Republik Indonesia rakyat memilih sendiri pemimpinnya.

Demokrasi banyak di suarakan diera reformasi. Namun mencari definisi demokrasi dalam konstitusi tidak mudah. Dalam UUD' 45 hanya terdapat dua kata demokrasi , satu dalam bentuk kata sifat yakni, 
"Demokratis" dan "Demokrasi". Pertama dalam pasal 18 yang menyebutkan pemilihan kepala daerah dipilih secara demokratis dan pada pasal 33 soal Demokrasi Ekonomi. Tafsir demokrasi seakan diarahkan kepada siapapun. Laboratorium demokrasi, seperti dikatakan Christina, masih terus berjalan. Eksperimen demokrasi mewujud dengan pemungutan suara, voting menjadi kata kunci. Mayoritas minoritas menang atau kalah. Kita sedang dihadapkan pada keprihatinan dimana demokrasi yang mewujud dalam pilkada menghadirkan pimpinan yang terjerat kasus korupsi atau pimpinan yang menjadi actor penghambat kebebasan beragama. Faried Zakaria mengutip diplomat Amerika, Richard Hoobroke, "Anggaplah pemilu berjalan bebas dan aktif . Dan mereka yang terpilih adalah orang rasio fases. Separatis yang secara terbuka menentang perdamaian”, itiu bisa terjadi dalam demokrasi. Demokrasi bisa berkembang, tetapi kebebasan konstitusional tidak.

Jadi Snyder dalam From Voting convidence (2000) menyampaikan pesan " membangun demokrasi bukan hanya menyingkirkan penguasa otoriter, dan selanjutnya demokrasi akan langsung”. Snyder berpesan hati - hati menyelenggarakan demokrasi karena berpotensi memunculkan guncangan. Transisi demokrasi di Indonesia membuat demokrasi menjadi suatu yang eksplosif. Karena eksplosif sering tanpa kontrol, ditambah factor lainnya Negara, sering terjadi eksplosif berujung pada anarki.

Pusat informasi kompas mencatat, dalam kurun waktu Mei 2005 - Juli 2010 paling tidak terjadi 49 kali konflik horisontal akibat pemilihan kepala daerah. Protes masa berubah menjadi anarki yang mengerikan. Gejala eksplosi demokrasi mulai memunculkan kesadaran baru. Ketua Makamah Konstitusi Mahfud MD menyatakan,pemilihan kepala daerah langsung perlu ditinjau ulang. Alasannya, Pilkada langsung merusak moral masyarakat. Kerusuhan itu massif, karena melibatkan seluruh rakyat. (Tempo 3 Agustus 2010). Apapun yang sebenarnya terjadi dalam eksperimen demokrasi Indoinesia? Prof. Azyuwardi, Guru besar Universitas Islam Negri Jakarta, menyebutkan euforia demokrasi tidak berjalan sejajar dengan peningkatan pemahaman soal demokrasi itu sendiri. Kebebasan kerap di salah artikan sebagai kebebasan tanpa aturan (lawlessness freedom) dan tanpa kepatuhan pada hukum.

Gejala kekerasan yang terjadi menunjukkan masih jauhnya pemahaman demokrasi sebagai art of compromise. Menjalani demokrasi masih menjadi sesuatu yang baru. Demokrasi tidak cukup bisa dikembangkan sendiri, ia harus disesuaikan, di pupuk secara terencana. la membutuhkan pendidikan kewargaan yang mencakup Democratif education, Civic education dan eititership education.

Dalam pidato 1 Juni 1945 didepan anggota Dokuritzes zymbi tyoosakai, Soekarno berpidato:

"Dasar itu jalan dasar mufakat, dasar perwakilan dan permusyawaratan. Negara Indonesia bukan satu Negara untuk satu orang, bukan Negara untuk satu golongan, walaupun golongan kerja. Tetapi kita mendirikan Negara, semua buat semua, satu buat semua, semua buat satu. Saya yakin bahwa syarat yang mutlak untuk kuatnya Negara Indonesia ialah permusyawaratan perwakilan ." (Tjamkan Pantja sila - sila dasar filsafat Negara, editor Amin Aryoso, 2002, hal25). "Apa - apa yang belum memuaskan, kita bicarakan didalam permusyawaratan," tulis Soekarno. Sedangkan bagi Muhamad Hatta, ada lima kasus demokrasi khas Indonesia yaitu, rapat, mufakat, gotong royong, hak mengajukan protes bersama, dan hak menyingkir dari wilayah kekuasaan raja yang tidak adil.

Musyawarah mufakat menjadi kata kunci, tetapi proses politik menengahkan pudarnya musyawarah untuk mufakat. Tren baru mengarah pada demokrasi tradisional. Partai politik menjadi penyewa 
perahu bagi kandidat untuk maju dalam pilkada dan itu uang. Kandidat Gubernur harus membayar konsultan politik untuk memacu citra dan itu berarti uang. Kandidatpun harus memberikan uang kepada pemilih.

Kapital menjadi salah satu faktor penting. Era pragmatisme tiba. Tak heran jika calon Gubernur harus menyiapkan dana puluhan milliard rupiah untuk maju dalam pilkada. Lalu bagaimana dengan mereka yang tidak memiliki capital? Akankah politik dikuasai kelompok berkapital besar?. Apa yang terjadi sekarang ini mengingatkan kita pada tulisan Soekarno 69 tahun yang lalu dalam pemandunya, 1941. Soekarno menulis , “.......karena biasanya kaum borjuislah yang mendapat banyak kursi. Mereka kaum borjuis, punya radio -radio, mereka punya gereja - gereja , mereka punya partai - partai, semuanya itu biasanya dapatlah menjamin suara terbanyak bagi kaum borjuis. Semuanya itu menjamin bahwa biasanya utusan - utusan rakyat jelata kalah suara" (di bawah bendera revolusi, 1965) halaman 586. Eksperimen demokrasi yang berjalan hampir delapan tahun seharusnya menciptakan kesadaran baru. Demokrasi tak mungkin dilepas dan diserahkan kepada para pelaku untuk menafsirkan sendiri bagaimana dengan demokrasi di praktekkan. Demokrasi politik juga tak akan bisa bertahan tanpa demokrasi ekonomi yang bermakna keadilan sosial. Pemimpin Visioner dibutuhkan. Diskursus soal kerakyatan musyawarah mufakat perlu dimunculkan. Pendidikan demokrasi menjadi keniscayaan di tengah pergerakan demokrasi yang tak terkontrol. Essensi mufakat yang terhadang dalam Pancasila perlu dibumikan dalam proses politik.

Peringatan 65 Tahun kemerdekaan menjadi momen tempat bagi kita untuk melihat relasi Pancasila, konstitusi, undang - undang serta perilaku politik. Dengan upaya itu, kita bisa selamat dalam menjalani eksperimentasi demokrasi di Indonesia ( Budiman Tanuredjo, kompas, Jumat 13 Agustus 2010).

\section{E. KEADILAN YANG SELALU DI DAMBAKAN.}

Tidak ada persatuan, kedamaian, dan kemakmuran yang merata tanpa keadilan. Ketidakadilan membuat frustasi, lalu memicu manusia berkonflik, berperilaku anarki menggilas perikemanusiaan. Maka rakyatpun rindu berjumpa keadilan itu.

Acapkali kemiskinan dituding sebagai kambing hitam penyebab masyarakat frustasi dan cepat marah, lalu mengekspresikannya dengan tindakan anarki. Tetapi terlupakan bahwa kemiskinan terjadi antara lain karena ketidakadilan.

Keadilan sosial bagi seluruh rakyat Indonesia, sila kelima Pancasila, itupun masih sebatas kata magis dan retorik. Rindu rakyat berjumpa keadilan kian membucah.

Di jalan - jalan raya, misalnya, keadilan amat terasa. Tidak ada ruang bagi pejalan kaki, jalur khusus motor dan sepeda. Kalau di jalan Raya saja belum tampak, bagaimana keadilan bisa tumbuh subur di wilayah dan aspek kehidupan yang tidak terlihat. Padahal nyata terasa jauh dalam hati nurani rakyat. Pencuri kakau, pencoleng sehelai karcis, bisa diproses hukum secepat kilat dengan hukuman yang nyaris tidak masuk akal. Hukum yang tidak adil itu justru mencabik - cabik logika dan rasa keadilan manakala koruptor kakap yang merampas kemanusiaan yang adil dan beradab bisa melenggang bebas. Tersangka korupsi bisa dipilih memimpin lembaga eksekutif dan legislative. Kebijakan 
pemerintah pada masa lalu sering kali dinilai rasakan diskriminatif dan membekas sampai kini. Dalam hal perlakuan antara pengusaha besar dan pengusaha kecil, ketimpangan pembangunan jawa dan luar jawa, kawasan timur dan barat, sekedar contoh nyata ketidak adilan itu.

Perasaan diperlakukan tidak adil itulah yang membuat sebagian orang Aceh " berontak " dan menuntut kemerdekaan, mencederai harga mati NKRI. Papua tetap "memanas ", juga karena perasaan ketidak adilan. Papua dan Aceh merasa kekayaan alamnya dikuras habis, tetapi tidak seimbang nilai yang dikembalikan untuk membangun dan memakmurkan perikehidupan mereka.

Bagaimana Negara ( Pemerintah) bisa menyatakan sudah berlaku adil manakala banyak di antara orang suku Dayak tak punya tanah sejengkalpun, sementara hutan dan lahan beserta seisi perut bumi Kalimantan telah di kapling pemodal sampai jutaan hektar luasnya karena kolusi yang koruptif.

\section{PIJAKAN PERTAMA}

Ibarat tangga menuju puncak peradaban kehidupan kita berbangsa dan bernegara, dengan Pancasila dan kelndonesiaan kita yang Bhineka Tunggal Ika sebagai dasarnya, keadilan sosial bagi seluruh rakyat Indonesias sejatinya menjadi anak tangga pertama yang harus di pijak. Keadilan dalam konteks aturan, kebijakan tindakan dan perolehan pemimpin terhadap rakyatnya dapat membuat masyarakat leluasa bermusyawarah dan bermufakat mencari solusi persoalannya.

Keadilan akan membuat bangsa lebih mudah menyatakan kekuatan membangun kemakmurannya yang bermartabat. Keadilan juga akan mempertebal rasa kemanusiaan dan saling mencintai sesame ciptaan Tuhan. Keadilan juga bisa membuat setiap orang tenang beribadah tanpa harus ketakutan tiba - tiba di serang kelompok lain yang berbeda keyakinan.

Ketika ketimpangan sosial semakin mencolok dalam kehidupan sehari - hari, keadilan memang harus di tegakkan dengan pembedaan dan pemihakan kepada mereka yang lemah dan tak beruntung. Sikap dasar, komitmen, pemimpin sangat menentukan. Kuncinya adalah kepribadian dan pembedaan demi rasa keadilan. Muhammad Yunus dari Banglades menerima hadiah Nobel perdamaian bukan karena ia turun ke medan perang, mendamaikan mereka yang berkonflik. la dianugerahi kehormatan itu karena pembelaannya terhadap orang miskin melalui pemberian kredit mikro yang tidak punya sumber daya sampai terentaskan dari kemiskinan. la menciptakan rasa keadilan, menghindari konflik, memupuk perdamaian, dan mengangkat martabat kemanusiaan.

Dalam konteks ke Indonesiaan kita, itulah hakekat demokrasi ekonomi yang tercantum "walau hanya sekali “ dalam konstitusi Negara Republik Indonesia. Implementasi keadilan sosial bagi seluruh rakyat Indonesia sejatinya tercermin dalam setiap aturan, kebijakan, dan praktek penyelenggaraan pemerintahan Negara. Kebijakan dan atutan - aturan hukum, terutama yang menyangkut eksploitasi dan pengelolaan sumber daya Nasional, khususnya sumber daya alam, harus berpihak kepada kepentingan nasional dan rakyat banyak. Bukan kepada golongan tertentu, apalagi jika lebih berpihak kepada kepentingan asing. Sumber daya alam Nasional bukanlah warisan untuk kita, melainkan amanah yang dititipkan kepada generasi sekarang untuk di wariskan kepada generasi mendatang. Janganlah kita mewariskan hutan gundul dan lahan kering kerontang. Tegakah kita meninggalkan tumpukan hutang kepada mereka?. Tentu kita tidak mau menorehkan catatan sejarah 
bahwa negeri ini dulu kaya raya, tetapi nyatanya generasi mendatang lebih banyak miskin dari sekarang. Kita mengingatkan kembali, betapa mulianya pemimpin yang berpikir dan bertindak adil dalam setiap langkahnya, tidak hanya memikirkan diri, kelompok dan golongannya suatu masa jabatannya.

Kita patut merenungkan anggaran Negara terus meningkat berkali - kali lipat, utang kita kian menumpuk, tapi orang miskin tetap tidak berkurang signifikan, pengangguran tetap panjang, dan pekerja informal makin berjubel, lalu pertumbuhan ekonomi tinggi, produk domestik bruto kian membesar, tetapi hutan makin gundul, isi perut bumi dan laut makin habis terkuras, tetapi rakyat banyak tak beranjak makmur.

Keadilan sosial menjadi utopia karena di korup oleh pemimpin yang serakah dan tak tahu diri, pemodal yang asosial dan nirsolidaritas. Cukuplah sudah keadilan dipidatokan. Terlalu picik menerjemahkan keberpihakan dan pembelaan hanya dengan memberikan subsidi dan membagikan bantuan langsung tunai kepada mereka yang miskin. Semestinya untuk mengantisipasi kesemuanya itu dengan cara tidak menjadikan bangsa Indonesia sebagai tempat konsumsi segala macam produk dari luar. Lihatlah sekarang ini semua manusia mempunyai ketergantungan HP, tidak perduli tua atau muda, juga tidak perduli pejabat atau tukang sampah mempunyai ketergantungan pada yang namanya HP. Demikian juga termasuk produk - produk motor dan mobil, Bangsa Indonesia menjadi tempat pasar dari luar dengan segala merek. Sampai sekarang ini pada bingung jalan - jalan di mana - mana macet semua.

Itulah semuanya baru produk - produk elektronik dan transportasi belum lagi sandang pangan kalau hal ini terus menerus di biarkan Indonesia tidak bisa mandiri dan aka nada ketergantungannya pada dunia luar. Mengapa kita tidak kembali kepada prinsip Bung Karno pada era jamannya. Investor tidak di perbolehkan masuk ke Indonesia, produk - produk dari luar tidak bebas masuk seperti sekarang ini, sehingga ada filternya. Dan mulai sekarang kita bangsa Indonesia sudah harus mulai selektif demi generasi mendatang yang tidak berketergantungan juga dengan memberdayakan seluruh komponen bangsa terutama riset dan teknologi, lembaga - lembaga peneliti dan lembaga - lembaga perguruan tinggi untuk mengembangkan teknologi tepat guna untuk memenuhi kebutuhan lokal baru nasional dengan membiayai lembaga - lembaga yang jelas menghasilkan produk - produk teknologi tepat guna dan kebutuhan - kebutuhan bangsa Indonesia secara umum.

Dengan demikian generasi mendatang memerlukan garis dan arah kebijakan nasional sekarang ini yang harus untuk mengangkat mereka dari keterpurukan dan membangun martabatnya berlandaskan amanat konstitusi UUD' 45 dan Pancasila sebagai dasar Negara Bangsa Indonesia. Sehingga bangsa Indonesia tidak tergantung pada dunia luar yang selalu merugikan bangsa Indonesia dan Insya Allah Indonesia akan jaya.

\section{F. KESIMPULAN DAN SARAN}

Dari paparan tersebut di atas dapat disimpulkan bahwa bangsa Indonesia mulai sekarang harus kembali ke Dasar Negara Pancasila, tidak hanya secara lahir saja tapi harus di maknai sampai mendalam. Pancasila harus di pelajari dan diamalkan dari lapisan paling atas sampai pada lapisan 
terbawah harus memahami Pancasila sebagai dasar Negara juga Pancasila sebagai Pandangan hidup Bangsa Indonesia yang sudah ditanamkan oleh Bapak - bapak pendiri Bangsa. Jangan mengingkari dan jangan munafik bahwa bangsa Indonesia perlu apa yang dinamakan Pancasila tersebut. Seperti apa yang dikatakan oleh Presiden Amerika, Barrach Obama, Bangsa Indonesia harus bangga punya Pancasila dan Bhineka Tunggal lka.

Selanjutnya Bangsa Indonesia sudah harus mulai mengurangi ketergantungan - ketergantungan produk luar baik alat komunikasi ataupun alat transportasi. Usahakan dengan daya upaya sendiri berusaha memproduksi sendiri dan Bangsa Indonesia berusaha untuk mandiri di tangan bangsa Indonesia sendiri. Dengan cara begini bangsa Indonesia terlepas dari belenggu produk - produk dari luar.

Disini juga disarankan mulai dari sekarang lembaga - lembaga resert baik LIPI, Menristek dan Perguruan -perguruan tinggi bergerak cepat melakukan resertnya dengan menghasilkan teknologi tepat guna dan produk - produk yang akan diperlukan Bangsa Indonesia dan Negara dapat mendukung dengan mendanai dari risert - risert tersebut yang dapat diharapkan hasilnya. 


\section{DAFTAR PUSTAKA}

1. Bikard Bagun,Kompas Senin 16 Agustus 2010.

2. Andi Suruji, Kompas, Sabtu 14 Agustus 2010

3. N Drijarkara, karya lengkap Drijarkara, Kanisius, 2006

4. ST Sularto, Kompas Selasa, 10 Agustus 2010.

5. Soemarno Soemarsono, karakter mengantar bangsa dari gelap menuju terang, PT Elex Komputindo, 2009.

6. Ninok Laksono, Kompas, 12 Agustus 2010 hal 1.

7. Tjamkan Pantja sila - sila dasar filsafat Negara, editor Amin Aryoso, 2002, hal25).

8. Di bawah bendera revolusi, 1965, halaman 586 .

9. Budiman Tanuredjo, kompas, Jumat 13 Agustus 2010). 